\title{
Status of the Name Proteus morganii and Designation of the Neotype Strain
}

\author{
ERWIN F. LESSEL \\ American Type Culture Collection, Rockville, Maryland 20852
}

In 1906, Morgan described a new bacterium, referred to merely as "Bacterium No. 1," which he isolated from the intestines and feces of patients suffering from infantile diarrhoea. The first to name this organism were Winslow et al. (1919), who called it Bacillus morgani (sic). Subsequent authors transferred Morgan's organism to a number of different genera. Among these was Rauss (1936), who stated that Morgan's bacillus belongs to "the Proteus group," but who did not use or propose a scientific name for the organism. In 1939 Yale described Morgan's "Organism No. 1" under the scientific name "Proteus morganii (Winslow et al.) Rauss." The questions arise whether the name Proteus morganii was validly published and, if so, by whom? It is clear that Yale was the first to propose the name $P$. morganii, although he attributed the name to Rauss, apparently because Rauss was the first to suggest placement of Morgan's bacillus in Proteus. Therefore it was Yale, not Rauss, who validly published the name $P$. morganii, and Yale, not Rauss, should be cited as the author of this name. ATCC 25830 (ATCC 8076h; NCTC 235), described herein, is designated as the neotype strain for P. morganii Yale.

In his studies on the bacteriology of summer diarrhoea of infants, Morgan (9) isolated a previously unrecognized organism of pathogenic importance from the intestines and feces of patients suffering from infantile diarrhoea. Morgan described the organism but did not name it, referring to it merely as Bacterium No. 1. Winslow et al. (14), the first to name the organism, called it Bacillus morgani (sic). [Although Winslow et al., the authors who first named this organism, spelled the specific epithet as "morgani," the epithet has been orthographically corrected to "morganii" in accordance with Recommendation $27 \mathrm{e}(2)$ of the Bacteriological Code (see reference 8).] Subsequently the organism was placed in the genus Salmonella by Castellani and Chalmers (2), in Bacterium by Holland (7), in Escherichia by Thj $\phi$ tta (13), and in Morganella by Fulton (6). Rauss (10) stated that "Morgan's bacillus No. 1" belonged to the "Proteus group." However, Rauss neither used nor proposed a scientific name for Morgan's organism. Yale (15) was the first to propose the name Proteus morganii for Morgan's bacillus No. 1. Although Yale cited Rauss (10) as the author of $P$. morganii, as mentioned above, Rauss neither used nor proposed this name. References to the name $P$. morganii subsequent to its proposal by Yale cite either Rauss $(4,5,11,12)$ or Yale (1) as the author. However, the indications are clear that Yale was the first to propose the name $P$. morganii even though he attributed the name to Rauss, apparently because Rauss was the first to place Morgan's bacillus in Proteus. Regardless of the reason why Yale cited Rauss as the author, the fact remains that it was Yale who made the combination $P$. morganii, and Yale, not Rauss, should be cited as the author of the name Proteus morganii.

It appears that none of Morgan's original isolates of the organism now known as $P$. morganii exist; therefore a neotype strain should be designated.

\section{MATERIALS AND METHODS}

Strain. ATCC 25830 (= ATCC $8076 \mathrm{~h}=$ NCTC 235 = $33 \mathrm{MO}$ ) was isolated by $\mathrm{H}$. de R. Morgan from a case of diarrhoea.

Methods. Aside from the determination of pathogenicity, the methods used in characterizing the neotype strain are those given by Edwards and Ewing (3). In determining pathogenicity, Morgan fed young rats half an agar tubefull and young rabbits a whole tubefull of the organism. The animals usually died within $24 \mathrm{hr}$, death being preceded by violent diarrhoea. In the determination of pathogenicity of the 
TABLE 1. Description of Proteus morganii and its neotype strain

\begin{tabular}{|c|c|c|c|c|}
\hline \multirow{2}{*}{$\frac{\text { Characteristic }}{\text { Gram-negative rods } \ldots \ldots \ldots \ldots \ldots \ldots \ldots}$} & \multirow[t]{2}{*}{$\begin{array}{c}\text { Morgan's } \\
\text { Bacterium No. } 1^{a}\end{array}$} & \multirow{2}{*}{$\begin{array}{l}\text { Neotype strain } \\
(\text { ATCC 25830) } \\
+\end{array}$} & \multicolumn{2}{|c|}{$\begin{array}{l}\text { Proteus morganiib } \\
\qquad(\%+)\end{array}$} \\
\hline & & & + & $(100)$ \\
\hline Motility . . . . . . . . . . . . . & + & + & \pm & $(88)$ \\
\hline Peritrichous (Fig. 1) $\ldots \ldots \ldots \ldots \ldots \ldots$ & + & + & + & $(100)$ \\
\hline Oxidase $\ldots \ldots \ldots \ldots \ldots \ldots \ldots \ldots \ldots \ldots \ldots \ldots \ldots \ldots$ & & - & - & $(0)$ \\
\hline Nitrate reduction $\ldots \ldots \ldots \ldots \ldots \ldots$ & & + & + & $(100)$ \\
\hline Potassium cyanide $\ldots \ldots \ldots \ldots \ldots \ldots$ & & + & + & $(98.5)$ \\
\hline Phenylalanine deaminase $\ldots \ldots \ldots \ldots \ldots$ & & + & + & $(100)$ \\
\hline Hydrogen sulfide $\ldots \ldots \ldots \ldots \ldots \ldots$ & & - & - & $(0)$ \\
\hline Gelatin liquefaction $\ldots \ldots \ldots \ldots \ldots$ & & - & - & $(0)$ \\
\hline Pectate liquefaction $\ldots \ldots \ldots \ldots \ldots$ & & - & - & $(0)$ \\
\hline Indole $\ldots \ldots \ldots \ldots \ldots \ldots \ldots \ldots$ & + & + & + & $(100)$ \\
\hline Methyl red $\ldots \ldots \ldots \ldots \ldots \ldots \ldots$ & & + & + & $(90.5)$ \\
\hline Voges-Proskauer . . . . . . . . . . . . & & - & - & $(0)$ \\
\hline Citrate (Simmons) . . . . . . . . . . . & & - & - & $(2.6)$ \\
\hline Malonate $\ldots \ldots \ldots \ldots \ldots \ldots \ldots$ & & - & & \\
\hline Litmus milk (alkaline) . . . . . . . . . . & + & & & \\
\hline Lysine decarboxylase $\ldots \ldots \ldots \ldots \ldots$ & & - & - & $(2.6)$ \\
\hline Arginine dihydrolase $\ldots \ldots \ldots \ldots \ldots \ldots$ & & - & - & $(0)$ \\
\hline Ornithine decarboxylase $\ldots \ldots \ldots \ldots \ldots$ & & + & + & $(100)$ \\
\hline Urease $\ldots \ldots \ldots \ldots \ldots \ldots \ldots \ldots \ldots$ & & + & + & $(100)$ \\
\hline Adonitol $\ldots \ldots \ldots \ldots \ldots \ldots \ldots \ldots$ & & - & - & $(0)$ \\
\hline Amygdalin $\ldots \ldots \ldots \ldots \ldots \ldots \ldots$ & - & - & & \\
\hline Arabinose $\ldots \ldots \ldots \ldots \ldots \ldots \ldots \ldots \ldots \ldots \ldots \ldots \ldots$ & - & - & & \\
\hline Cellobiose $\ldots \ldots \ldots \ldots \ldots \ldots \ldots \ldots$ & & - & & \\
\hline 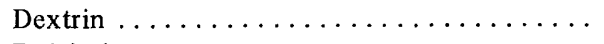 & - & - & & \\
\hline Dulcitol $\ldots \ldots \ldots \ldots \ldots \ldots \ldots \ldots$ & - & - & & \\
\hline Erythritol $\ldots \ldots \ldots \ldots \ldots \ldots \ldots \ldots$ & - & - & & \\
\hline Fructose $\ldots \ldots \ldots \ldots \ldots \ldots \ldots \ldots \ldots \ldots \ldots \ldots \ldots \ldots$ & $+/+$ & + & & \\
\hline Galactose $\ldots \ldots \ldots \ldots \ldots \ldots \ldots \ldots$ & $+1+$ & $+1+$ & & \\
\hline Glucose $\ldots \ldots \ldots \ldots \ldots \ldots \ldots \ldots$ & $+/+$ & $+1+$ & $+/+$ & $(100 / 95.5)$ \\
\hline Glycerol $\ldots \ldots \ldots \ldots \ldots \ldots \ldots \ldots$ & & $(+)$ & & \\
\hline Inositol $\ldots \ldots \ldots \ldots \ldots \ldots \ldots \ldots \ldots \ldots \ldots \ldots \ldots$ & & - & - & $(0)$ \\
\hline Inulin $\ldots \ldots \ldots \ldots \ldots \ldots \ldots \ldots \ldots \ldots \ldots \ldots \ldots \ldots \ldots$ & - & - & & \\
\hline 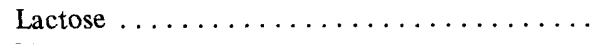 & - & - & & \\
\hline Maltose $\ldots \ldots \ldots \ldots \ldots \ldots \ldots \ldots$ & - & - & - & $(0)$ \\
\hline Mannitol $\ldots \ldots \ldots \ldots \ldots \ldots \ldots \ldots \ldots \ldots \ldots \ldots \ldots \ldots$ & - & - & - & $(0)$ \\
\hline Raffinose $\ldots \ldots \ldots \ldots \ldots \ldots \ldots \ldots$ & - & - & & \\
\hline Rhamnose $\ldots \ldots \ldots \ldots \ldots \ldots \ldots \ldots$ & & - & & \\
\hline Salicin $\ldots \ldots \ldots \ldots \ldots \ldots \ldots \ldots \ldots \ldots \ldots \ldots \ldots \ldots \ldots \ldots$ & - & - & - & $(0)$ \\
\hline Sorbitol $\ldots \ldots \ldots \ldots \ldots \ldots \ldots \ldots \ldots \ldots \ldots \ldots \ldots$ & - & - & & \\
\hline Sucrose $\ldots \ldots \ldots \ldots \ldots \ldots \ldots \ldots$ & - & - & - & $(9.5)$ \\
\hline Trehalose $\ldots \ldots \ldots \ldots \ldots \ldots \ldots \ldots$ & & - & & \\
\hline Xylose..$\ldots \ldots \ldots \ldots \ldots \ldots \ldots \ldots$ & & - & - & $(0)$ \\
\hline Pathogenicity: & & & & \\
\hline rabbits $\ldots \ldots \ldots \ldots \ldots \ldots \ldots \ldots$ & + & - & & \\
\hline 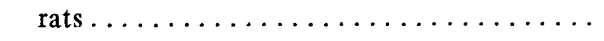 & + & - & & \\
\hline
\end{tabular}

$a$ Morgan (reference 9, p. 910).

$b$ Edwards and Ewing (reference 3, p. i, iv, and 231).

neotype strain, albino rats approximately 8 weeks old and weighing between 101 and $125 \mathrm{~g}$ and albino rabbits approximately 6 weeks old and weighing between $3 \mathrm{lb}$ and $3 \mathrm{lb}, 15 \mathrm{oz}$ were used. Each of the animals was fed $3 \mathrm{ml}$ of nutrient broth containing $1.52 \times 10^{12}$ organisms. Control animals were fed $3 \mathrm{ml}$ of sterile nutrient broth. The animals were observed for 9 days, during which time none of them died or became ill. 

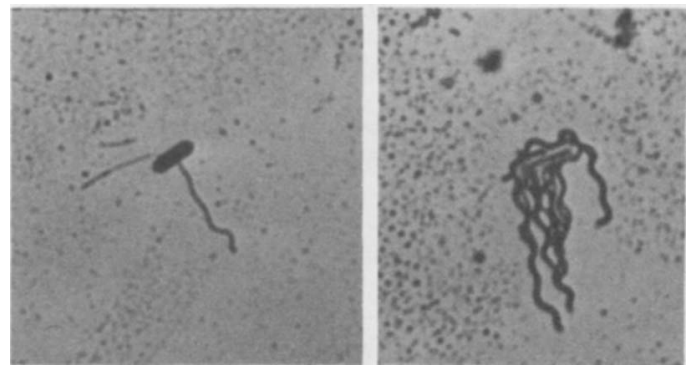

Fig. 1. Peritrichous cells of Proteus morganii ATCC 25830. Twenty-four-hour broth culture at 26 C. Staining by Leifson's method. $\times 1,200$. Left: single, lateral flagellum; this is frequently the predominant form. Right: multitrichous.

\section{DISCUSSION}

Winslow et al. (14) regarded strain 692 [ATCC 8076d; ATCC 25829 (ATCC, American Type Culture Collection, Rockville, Md.); NCTC 417 (NCTC, National Collection of Type Cultures, London)] of the American Museum of Natural History collection as the type of Bacillus morgani. However, this strain was isolated by $\mathrm{H}$. E. Smiley from the stool of an infant at the Providence City Hospital, Providence, R.I. Because this strain is not one of the strains on which Morgan's original description was based, it cannot be designated as the type strain. Although one of Morgan's strains of this organism does exist (ATCC 25830), there is no evidence that it is one of the strains on which he based his original description. Strain ATCC 25830 is therefore here designated as the neotype strain of $P$. morganii. A description of the neotype strain as well as the original description of organism no. 1 by Morgan and a description of the current concept of $P$. morganii are given in Table 1 . From the data presented, it is clear that the characters of ATCC 25830 , the neotype strain of $P$. morganii, agree not only with those recorded in Morgan's original description (with the exception of pathogenicity) but also with the current concept of $P$. morganii. There are many factors which affect pathogenicity, and for this reason pathogenicity is generally of little value as a taxonomic characteristic. Therefore, the fact that the neotype strain does not agree with respect to pathogenicity with the original description does not detract from its suitability to serve as the neotype. The neotype strain does possess all of those characteristics of $P$. morganii which are currently of taxonomic and diagnostic importance.

\section{ACKNOWLEDGMENTS}

The assistance of Shirley Landon, Charles Mills (pathogenicity tests), and $\mathrm{H}$. Hatt (photomicrographs of flagellated cells) in characterizing the neotype strain is gratefully acknowledged.

\section{LITERATURE CITED}

1. Buchanan, R. E., J. G. Holt, and E. F. Lessel, Jr. 1966. Index Bergeyana, The Williams \& Wilkins Co., Baltimore.

2. Castellani, A., and A. J. Chalmers. 1919. Manual of tropical medicine, $3 \mathrm{rd}$ ed. William Wood and Co., New York.

3. Edwards, P. R., and W. H. Ewing. 1961. Identification of Enterobacteriaceae. Burgess Publishing Co., Minneapolis.

4. Ewing, W. H. 1963. An outline of nomenclature for the family Enterobacteriaceae. Int. Bull. Bacteriol. Nomen. Taxon. 13(2):95-110.

5. Ewing, W. H. 1970. Differentiation of Enterobacteriaceae by biochemical reactions. U.S. Dept. of Health, Education and Welfare, Public Health Service.

6. Fulton, M. 1943. The identity of Bacterium columbensis Castellani. J. Bacteriol. 46:79-82.

7. Holland, D. F. 1920 . V. Generic index of the commoner forms of bacteria, p. 215-229. In C.-E. A. Winslow, J. Broadhurst, R. E. Buchanan, C. Krumwiede, Jr., L. A. Rogers, and G. H. Smith, The families and genera of the bacteria. J. Bacteriol. 5:191-229.

8. International Code of Nomenclature of Bacteria 1966. Int. J. Syst. Bacteriol. 16(4):459-490.

9. Morgan, H. de R. 1906. Upon the bacteriology of the summer diarrhoea of infants. Brit. Med. J. 1:908-912.

10. Rauss, K. F. 1936. The systematic position of Morgan's bacillus. J. Pathol. Bacteriol. 42:183-192.

11. Stuart, C. A. 1957. Genus VIII. Proteus Hauser, p. 364 -366. In R. S. Breed, E. G. D. Murray, and N. R. Smith (ed.), Bergey's manual of determinative bacteriology, 7 th ed. The Williams \& Wilkins Co., Baltimore.

12. Stuart, C. A., and R. Rustigian 1948. Genus I, Proteus Hauser, p. 486-491. In R. S. Breed, E. G. D. Murray, and A. P. Hitchens (ed.), Bergey's manual of determinative bacteriology, 6th ed. The Williams \& Wilkins Co., Baltimore.

13. Thjøtta, T. 1928. Septic infection due to Bacterium morgani 1. J. Infec. Dis. 43:348-352.

14. Winslow, C.-E. A., I. J. Kligler, and W. Rothberg 1919. Studies on the classification of the colontyphoid group of bacteria with special reference to their fermentative reactions. J. Bacteriol. 4:429-503.

15. Yale, M. W. 1939. Genus VI. Proteus Hauser, p. 430-436. In D. H. Bergey, R. S. Breed, E. G. D. Murray, and A. P. Hitchens (ed.), Bergey's manual of determinative bacteriology, 5 th ed. The Williams \& Wilkins Co., Baltimore. 